\title{
Article \\ Probiotic Effects and Metabolic Products of Enterococcus faecalis LD33 with Respiration Capacity
}

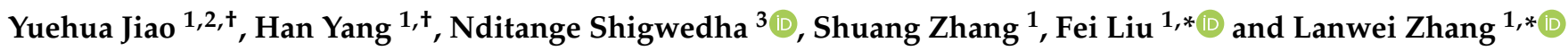 \\ 1 Key Laboratory of Dairy Science-Ministry of Education, Food College, Northeast Agricultural University, \\ Harbin 150030, China; ava_1@126.com (Y.J.); y18166877720@163.com (H.Y.); szhang@neau.edu.cn (S.Z.) \\ 2 Center of Drug Safety Evaluation, Heilongiiang University of Chinese Medicine, Harbin 150040, China \\ 3 School of Chemistry and Chemical Engineering, Harbin Institute of Technology, Harbin 150090, China; \\ nditange@yahoo.com \\ * Correspondence: liufei@neau.edu.cn (F.L.); zhanglanwei@ouc.edu.cn (L.Z.) \\ + These authors contributed equally to this work.
}

check for

updates

Citation: Jiao, Y.; Yang, H.; Shigwedha, N.; Zhang, S.; Liu, F.; Zhang, L. Probiotic Effects and Metabolic Products of Enterococcus faecalis LD33 with Respiration Capacity. Foods 2022, 11, 606. https://doi.org/10.3390/ foods 11040606

Academic Editor: Maria Rosaria Corbo

Received: 11 December 2021 Accepted: 17 February 2022 Published: 20 February 2022

Publisher's Note: MDPI stays neutral with regard to jurisdictional claims in published maps and institutional affiliations.

Copyright: (C) 2022 by the authors. Licensee MDPI, Basel, Switzerland. This article is an open access article distributed under the terms and conditions of the Creative Commons Attribution (CC BY) license (https:// creativecommons.org/licenses/by/ $4.0 /)$.

\begin{abstract}
Respiration metabolism could improve the long-term survival of lactic acid bacteria (LAB); however, its effect on potential probiotic traits of LAB was not reported. The difference made by Enterococcus faecalis LD33 that was cultured under respiration-permissive and fermentation conditions, such as the biomass, metabolites, antimicrobial activity, tolerance to acid and bile salt, adhesion capabilities, and the ability to inhibit the proliferation of cancer cells were studied. Under a respirationpermissive condition, the final biomass of the culture was about twice as compared to that of fermentation condition. When the metabolites were measured, glucose was exhausted within $8 \mathrm{~h}$. Two-folds of acetic acid, triple of both acetoin and diacetyl, and less than half of lactic acid, were accumulated under the respiratory-permissive condition. No discrimination of growth inhibition on Salmonella enterica serovar Typhimurium ATCC 14028 and Shigella sonnei ATCC 25931 was observed when Enterococcus faecalis LD33 was cultured under both conditions; however, under respirationpermissive condition, the strain presented significant antimicrobial activities to Listeria monocytogenes ATCC19111 and Staphylococcus aureus ATCC6538P. Enterococcus faecalis LD33 displayed relatively strong bile salt tolerance and adherence capability but weaker acid tolerance when undergoing respiration metabolism. There was no significant difference in the anti-cancer effect of the viable bacterial cells on both growth modes; however, the supernatant showed a higher inhibition effect on HT-29 cells than the live bacteria, and there was no significant difference between the supernatant and the 5-Fluorouracil ( $7 \mu \mathrm{g} / \mathrm{mL})$. Consequently, the Enterococcus faecalis LD33 undergoing respiration metabolism could bring higher biomass, more flavor metabolites, and better antimicrobial and anticancer activities. This study extends our knowledge of respiratory metabolism in LAB and its impact on probiotic traits. E. faecalis LD33 qualifies as a suitable strain against foodborne pathogens, cancer therapy, and eventual application in the food and pharmaceutical industries.
\end{abstract}

Keywords: Enterococcus faecalis; respiration; probiotics; metabolic products

\section{Introduction}

Lactic acid bacteria (LAB) are a phylogenetically diverse group named for their principal attribute in food fermentations, that is, the production of lactic acid [1]. Lactic acid finally inhibits the growth of LAB when accumulated in the culture [2,3]. LAB play an important role in various kinds of fermented food, mainly in dairy products (cheese and yogurt), fermented vegetables (sauerkraut, kimchi, and pickles), fermented cereals (sourdough), soy sauce, and meat products (sausages) [4-7]. LAB also contribute significantly to other fermentation processes, such as wine production [8].

A demonstration of altered metabolic end products, cytochrome formation, and hemindependent oxygen uptake indicated that the electron transport chain and cytochromes existed in hemin grown cultures $[9,10]$. LAB of several species, including Lactococcus lactis, 
Enterococcus faecalis, Streptococcus and Lactobacillus [10-13], are genetically equipped for aerobic respiration, providing them with a double metabolic life. They can switch from fermentation to aerobic respiration metabolism if equipped with exogenous heme (and menaquinones for some species, especially Lactobacillus) [14-16]. Respiration metabolism in Lactococcus lactis has been well documented, and it has a positive and significant impact on the bacterial biomass, $\mathrm{O}_{2}$ resistance, and long-term survival [10,17]. Consequently, the growth and survival of several strains of LAB can be dramatically improved under respiration-permissive conditions [18-20]. Furthermore, aerobic respiration positively impacts on the robustness and stress resistance of the strains, which can be beneficial for usage in food fermentation as probiotics and starter cultures [21-23].

Enterococci belong to $\mathrm{LAB}$ and are of importance in food fermentation; however, there are relatively few published reports about Enterococcal strains as probiotics compared to probiotic Lactobacillus strains. Certain Enterococci have been successfully used as probiotics to improve human or animal health. E. faecium SF68 [24-26] was the best known and probably the best researched probiotic Enterococcus strain in treating diarrhea and as an alternative to antibiotic treatment [27]. This strain showed the ability to inhibit the growth of E. coli, Salmonella serovars, Shigella spp. and Enterobacter spp., and equally could enhance the immune response to Giardia intestinalis in mice [28]. In vitro, it was shown to be resistant to low $\mathrm{pH}$ and tolerant to bile [29].

These findings opened up a new prospect on the LAB lifestyle, which must be understood to exploit their full potential $[5,16]$. Therefore, this study aimed to determine the differences of E. faecalis LD33 undergoing the lifestyle of fermentation and respiration at biomass, $\mathrm{pH}$ and fermentation metabolites in each period of the whole growth, at the inhibition effect of various indicator bacteria, at acid and bile tolerance, at the adhesion effect and inhibition effects of HT-29 human colon cancer cells. To our knowledge, this is the first comparison of the probiotic effects and the metabolites of the Enterococci when undergoing respiration and fermentation growth. In order to develop and use the benefits of E. faecalis LD33 brought by both metabolic styles, it was worthy of doing in-depth research on the strain that may be beneficial for future industrial exploitation when its safety is certified.

\section{Materials and Methods}

\subsection{Strain and Growth Conditions}

The strain LD33 used in this study was 1 of 18 strains isolated from the Inner Mongolia herders' homemade cream. The strain was identified as E. faecalis by using the API $50 \mathrm{CH}$ system (bioMérieux, Marcy l'Etoile, France) and analysis of 16S rDNA gene sequences. E. faecalis LD33 was cultured in an enriched M17 medium supplemented with $1 \%$ glucose (GM17). The strain was subcultured twice at $30^{\circ} \mathrm{C}$ for $18 \mathrm{~h}$ before use. Hemin (SigmaAldrich, St. Louis, MO, USA) stock solution $(0.5 \mathrm{mg} / \mathrm{mL}$ ) was prepared (in $0.05 \mathrm{~mol} / \mathrm{L}$ $\mathrm{NaOH}$ ) and then pasteurized at $115^{\circ} \mathrm{C}$ for $15 \mathrm{~min}$. Twenty (20) $\mu \mathrm{L}$ of hemin stock solution was added to $1 \mathrm{~mL}$ of the medium. After inoculation with $3 \%(v / v)$ pre-cultures (routinely non-aerated cultures grown overnight in medium lacking hemin) in fresh GM17 medium with and without hemin respectively in Erlenmeyer flasks (filled to less than 1/10-volume capacity), growth experiments under the specified conditions were performed. Non-aerated cultures were grown without agitation and without hemin in the medium (fermentation conditions, FC), and aerated cultures were grown with shaking (250 rpm) and hemin $(10 \mu \mathrm{g} / \mathrm{mL})$ in the medium (respiration-permissive conditions, RPC). Aliquots of prepared cells were removed (at different times) for optical density $\left(\mathrm{OD}_{600}\right)$ and $\mathrm{pH}$ measurements.

\subsection{Metabolic Products Determination}

Samples of $2 \mathrm{~mL}$ cultures were collected at appropriate harvesting time $(1,2,3,4$, $5,6,7,8,9,10,11,12,14,17,21$ and $24 \mathrm{~h}$ ) after the start of growth under FC and RPC, and centrifuged at $9000 \times g$ for $5 \mathrm{~min}$ to remove the bacteria, and then the supernatants were stored at $-20^{\circ} \mathrm{C}$ until use. Before quantifying of glucose, lactate, acetate, acetoin and diacetyl, the supernatants were filtered through a $0.22 \mu \mathrm{m}$ pore-size filter. The high-pressure 
liquid chromatography (HPLC 2695, Waters Corporation, Milford, MA, USA) was used for the determination as reported by Andersen et al. [30] and Starrenburg and Hugenholtz [31] with some modifications. Separation was performed with an Aminex HPX-87H column $(300 \times 7.8 \mathrm{~mm}$, pre-packed HPLC carbohydrate analysis column, hydrogen form, $9 \mu \mathrm{m}$ particle size, $8 \%$ cross-linkage, Bio-Rad, Richmond, CA, USA). $\mathrm{H}_{2} \mathrm{SO}_{4}(5 \mathrm{mmol} / \mathrm{L})$ was used as the mobile phase at a $0.5 \mathrm{~mL} / \mathrm{min}$ flow rate. All products were detected by the Refractive Index Detector 2414 (Waters Corporation, Milford, MA, USA). The sample injection volume was $10 \mu \mathrm{L}$, the column temperature was $65^{\circ} \mathrm{C}$ and the running time was $20 \mathrm{~min}$. All experiments were conducted twice in three replicas.

\subsection{Antibacterial Activity Assay}

An agar well diffusion assay (AWDA) was used for testing the antibacterial activity of the cell-free supernatants (CFSs) of E. faecalis LD33 growth under FC and RPC, as described by Ammor, Tauveron, Dufour and Chevallier [32] and Thirabunyanon et al. [33] with some modifications. Oxford cups (6 mm in diameter) were placed on the surface of $1.5 \%(w / v)$ sterilized agar plates, and then $15 \mathrm{~mL}$ semi-solid Tryptic Soy Agar (TSA) medium $(0.75 \%)$ containing $200 \mu \mathrm{L}$ of the selected pathogenic strain $\left(1.0 \times 10^{8} \mathrm{CFU} / \mathrm{mL}\right)$ were overlaid to form a double-plate. Hundred (100) $\mu \mathrm{L}$ of CFS of the strain eliminated the effect of organic acid, and hydrogen peroxide was placed in each well, formed after Oxford cups were removed from the solidified medium. The plates were then incubated for $24 \mathrm{~h}$ at $30^{\circ} \mathrm{C}$ and subsequently examined for inhibition zones. Inhibition was regarded as negative if no zone was observed around the wells. Each antibacterial activity was related to the diameter $(\mathrm{mm})$ of the inhibition zone displayed. Listeria monocytogenes (L. monocytogenes) ATCC 19111, Escherichia coli (E. coli) ATCC 25922, Staphylococcus aureus (S. aureus) ATCC 6538P, Salmonella enterica serovar Typhimurium (Salm. Serovar Typhimurium) ATCC 14028, Shigella sonnei (Sh. Sonnei) ATCC 25931 were used as indicator pathogen strains, and all of them were cultured in TSA medium.

In order to eliminate the inhibition of organic acids in the CFSs, the test supernatants were adjusted to $\mathrm{pH} 6.5$ with $4 \mathrm{~mol} / \mathrm{L} \mathrm{NaOH}$ and treated with catalase $(1 \mathrm{mg} / \mathrm{mL})$ to exclude the inhibition due to hydrogen peroxide production. The lactic acid of $\mathrm{pH} 6.5$ was used as a control. Proteinase K, Pepsin, and trypsin (at a final concentration of $3 \mathrm{mg} / \mathrm{mL}$ ) [34] were purchased from Sigma-Aldrich and used to validate the production of bacteriocin-like substances, respectively.

\subsection{Survival in Acid and Bile Salt}

To determine the tolerance of the strain under acidic conditions, the method of Watanabe et al. [35] was used with slight modifications. Overnight pre-cultures $\left(10^{9} \mathrm{CFU} / \mathrm{mL}\right)$ were inoculated $(1 \% v / v)$ in $25 \mathrm{~mL}$ of GM17 broth acidified to different $\mathrm{pH}(2.9,2.6,2.3$ and 2.0) with $1.0 \mathrm{~mol} / \mathrm{L} \mathrm{HCl}$, using unacidified broth as control. After incubation at $30^{\circ} \mathrm{C}$ for 30 min under FC and RPC, respectively, the viability of the bacterial cells was determined by plating them on a GM17 agar medium and then incubated at $30{ }^{\circ} \mathrm{C}$ for $72 \mathrm{~h}$. Acid tolerance of the strain was quantified from the number of viable cells, represented by $\log \left(\mathrm{N} / \mathrm{N}_{0}\right)$, whereby $\mathrm{N}$ and $\mathrm{N}_{0}$ are the CFU of the acidified group and the control group, respectively.

The ability of a strain to grow in the presence of bile was determined according to the method of Succi et al. [36] with some modifications. The strain was inoculated $(1 \% v / v)$ into GM17 broth with $0.3,0.5$ and $1 \%(w / v)$ of bile (Sigma-Aldrich). Cultures were incubated at $30{ }^{\circ} \mathrm{C}$ for $24 \mathrm{~h}$ under FC and RPC, respectively. The absorbency of each culture was measured at $600 \mathrm{~nm}$, using bile salt-free broth as a control. The results were expressed as:

$$
\text { Bile tolerance }(\%)=[\mathrm{OD}(\text { sample }) / \mathrm{OD}(\text { control })] \times 100 \%
$$

where, $\mathrm{OD}$ (sample) is $\mathrm{OD}_{600}$ of the culture containing bile salts; $\mathrm{OD}$ (control) is $\mathrm{OD}_{600}$ of the control culture without bile salts. 


\subsection{Adhesion Capability Assay}

The adhesion of the strain to HT-29 cells was examined using an assay previously described by Chauvière et al. [37] and Zhang et al. [38] with a slight modification. Briefly, the HT-29 monolayers were prepared in six-well tissue plates, washed twice with phosphatebuffered saline (PBS) (Sigma-Aldrich). For each adhesion assay, the strains incubated under FC and RPC were collected by centrifugation and suspended in RPMI-1640 (Hycolone, Utah, UT, USA), were then added to each well to reach a ratio of $100: 1$ ( $10^{8}$ bacteria $/ 10^{6}$ cell). After being incubated for $3 \mathrm{~h}$ at $37^{\circ} \mathrm{C}$ in $5 \% \mathrm{CO}_{2} / 95 \%$ air, the monolayers were washed 5 times with sterile PBS $\left(37^{\circ} \mathrm{C}\right)$ to remove un-adhered bacteria. Triton X-100 (0.1\%), purchased from Sigma (Deisenhofen, Germany), was used to lyse the cells and release the adhered cells from the wall by incubated them at $37^{\circ} \mathrm{C}$ for $30 \mathrm{~min}$. The mixture was serially diluted, and the appropriate dilutions were plated onto M17 agar plates before being cultured at $37^{\circ} \mathrm{C}$ for $48 \mathrm{~h}$. The adherence index was expressed by $\mathrm{CFU} / \mathrm{mL}$ for each mixture.

\subsection{Inhibition of HT-29 Human Colon Cancer Cells}

The 3-(4, 5-dimethylthiazol-2-yl)-2, 5-diphenyltetrazolium bromide (MTT) (SigmaAldrich) assay was carried out in 96 well tissue plates $[33,39]$ to test the inhibition to human colon cancer cells HT-29 of the strain. Fifteen (15) $\mu \mathrm{L}$ of HT-29 cell suspensions $\left(10^{5}\right.$ cells $\left./ \mathrm{mL}\right)$ and RPMI-1640 (120 $\mu \mathrm{L}$ for sample groups and $135 \mu \mathrm{L}$ for the control group) were dispensed into each well, and the plates were incubated at $37^{\circ} \mathrm{C}$ until almost all the cells were attached to the wall. The strains incubated under FC and RPC were centrifuged at $10,000 \times \mathrm{g}$ at $4{ }^{\circ} \mathrm{C}$ for $5 \mathrm{~min}$. The pellet was washed three times with PBS and then suspended in RPMI-1640. Four sample groups were evaluated in this study, including 3 groups of different concentrations of live bacteria $\left(10^{5}, 10^{6}\right.$ and $10^{7} \mathrm{CFU} / \mathrm{mL}$ suspended in $15 \mu \mathrm{L}$ of RPMI-1640, separately) and a group of CFS (15 $\mu \mathrm{L})$, and the samples were put into each well containing $135 \mu \mathrm{L}$ RPMI-1640. Five-Fluorouracil (5-FU, $7 \mu \mathrm{g} / \mathrm{mL}$ as the final concentration) was used as a positive control. After incubation at $37^{\circ} \mathrm{C}$ for $72 \mathrm{~h}$ in $5 \% \mathrm{CO}_{2} / 95 \%$ air, $10 \mu \mathrm{L}$ MTT solution $(0.5 \mathrm{mg} / \mathrm{mL}$ in PBS) was added to each well and incubated for another $4 \mathrm{~h}$ to form the formazan precipitates, and then were solubilized by adding $150 \mu \mathrm{L}$ DMSO. After $5 \mathrm{~min}$ incubation, the absorbance was measured at $490 \mathrm{~nm}$ by Eon's microplate reader (BioTek, Winooski, VT, USA). Results were presented as the inhibition rates. All results were transformed into percentages based on their respective controls, calculated using the following equation:

$$
\text { Inhibition rate } \%=\left[1-\mathrm{OD}_{(\text {Sample })} / \mathrm{OD}_{(\text {Control })}\right] \times 100 \%
$$

\subsection{Statistical Analysis}

The data obtained in this study were performed with SPSS 20.0 for Windows (SPSS Inc., Chicago, IL, USA) and expressed in means \pm SD ( $n=3$ independent experiment). Statistical significance analysis was determined using one-way analysis of variance (ANOVA, SPSS 20.0), and then Duncan's multiple range test was used for multiple comparisons. Values of $p<0.05$ were considered statistically significant.

\section{Results and Discussion}

\subsection{Respiration-Permissive Condition Leads to Biphasic Growth}

The growth and $\mathrm{pH}$ of E. faecalis LD33 at appropriate time cultured under state of fermentation and respiration were compared, and the results are shown in Figure 1. The growth kinetics of E. faecalis LD33 cultured under both conditions were primarily similar during the first $3 \mathrm{~h}$ of growth. At $4 \mathrm{~h}$ (entering the exponential phase), the cell density of the respiratory-grown culture was significantly higher than that of the fermentation culture. During 4-8 h of growth, the initial $\mathrm{pH}$ of 6.9 dropped dramatically to 5.6 (for RPC) and 5.7 (for FC), respectively. E. faecalis LD33 culture entered stationary phase at the 8th h, the biomass of RPC culture was about twice as much as that of FC culture. At the same time, 
the $\mathrm{pH}$ value of RPC culture encountered a breakpoint and began a slightly upward to final $\mathrm{pH}$ 5.8. In contrast, the final $\mathrm{pH}$ of FC cultures was as low as 4.6.

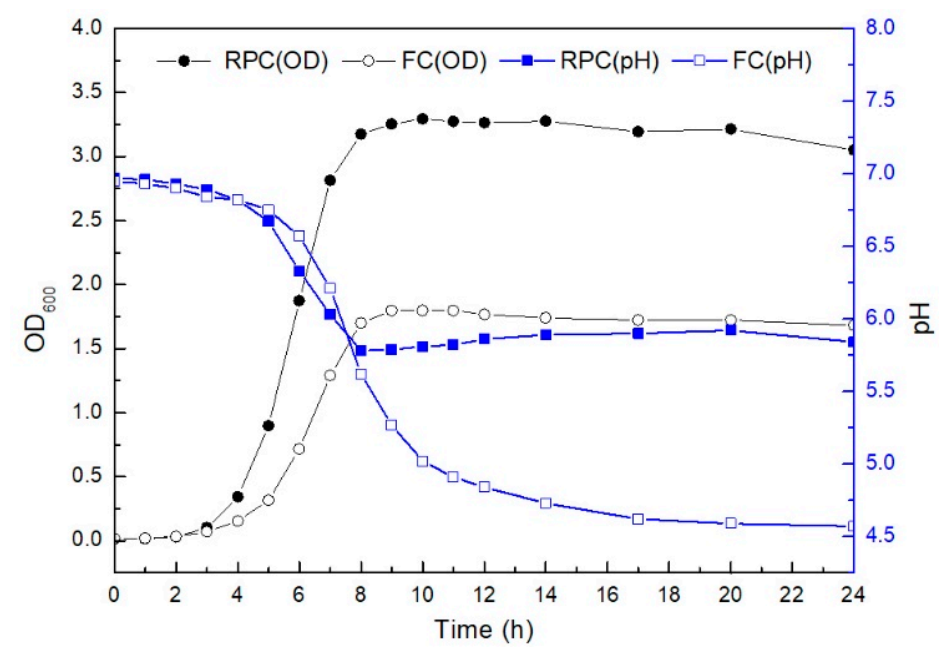

Figure 1. The differences in $\mathrm{OD}_{600}$ and $\mathrm{pH}$ for E. faecalis LD33 cultured under fermentative and respiration-permissive conditions respectively during the whole growth period $(24 \mathrm{~h})$, respectively. RPC and FC mean E. faecalis LD33 cultured under respiration-permissive and fermentation conditions, respectively.

The metabolic life of E. faecalis LD33 cultured under RPC was changed to the aerobic respiration metabolism at the very beginning of the exponential-growth phase period (at $4 \mathrm{~h}$ ). The $\mathrm{pH}$ value could also verify that some changes in metabolic pathways were happening at this very time (begin from $4 \mathrm{~h}$ ). Many experiments suggested that L. lactis can respire when oxygen and hemin are available $[9,12,14]$. In most of L. lactis, such as L. lactis MG1363 and L. lactis CHCC2862, the metabolism was altered just before the time when the cultures entered the stationary phase under fermentative conditions $[9,40]$. The metabolism of $L b$. plantarum WCFS1 was changed at the exponential stage [13]. Contrary to those studies, the time of E. faecalis LD33 metabolism was altered at the very beginning of the early exponential phase other than just before entering the stationary phase of L. lactis MG1363 and L. lactis CHCC2862 or the exponential phase of Lb. plantarum WCFS1. Thus, the time of strains entering respiration from fermentation may differ among different strains, which may also be affected by the growth condition $[9,22]$.

\subsection{Metabolites Altered by the Respiration-Permissive Condition}

Several metabolites were altered by respiration, including a considerable decrease in lactic acid accumulation and a substantial increase in acetoin and diacetyl accumulation. Both growth modes' metabolites of E. faecalis LD33 were measured at specified time intervals. The contents of glucose, lactate, acetate, acetoin and diacetyl at different times are shown in Figure 2 (a, b, c, and d, respectively). Note that there were slight differences in the growth kinetics of E. faecalis LD33, especially between medium batches. In Figure 2, the content of all these four metabolites were basically the same in the supernatant under FC and RPC within the first five hours of growth. The differences could be identified at the 6th $h$, and because of the initiation of the exponential phase, a large amount of glucose was consumed. By the 8th h, glucose in the supernatant under RPC was exhausted. 


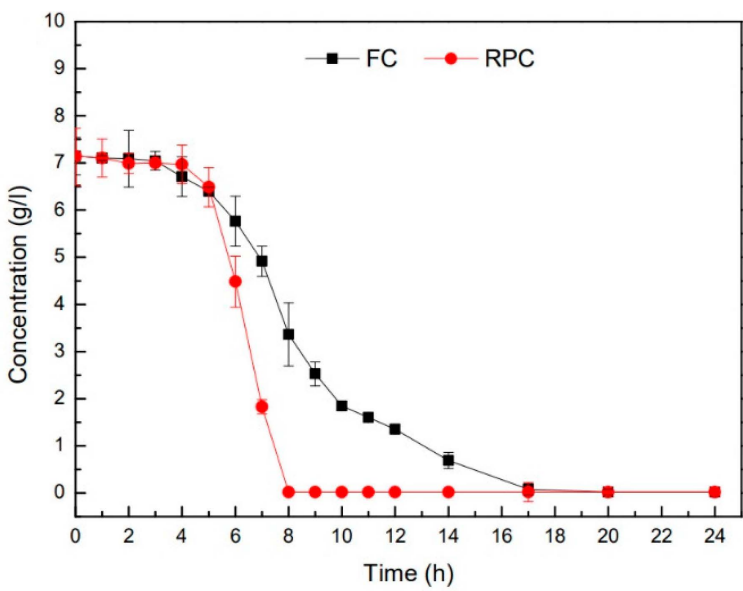

(a)

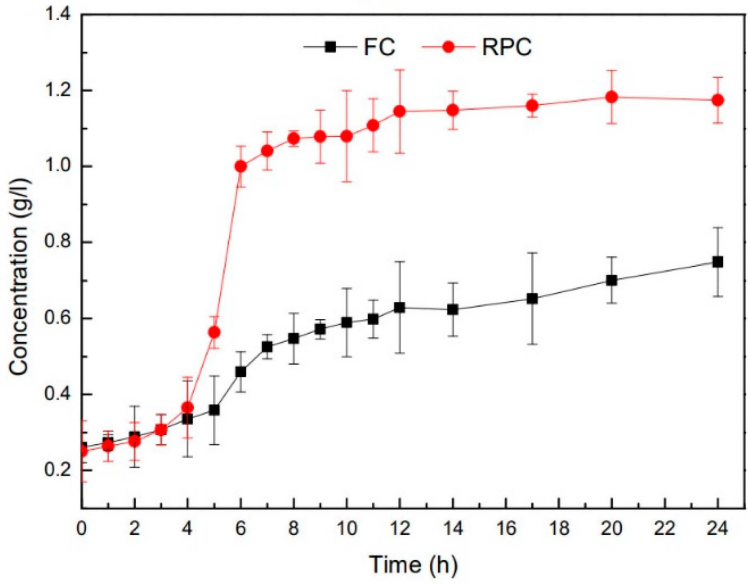

(c)

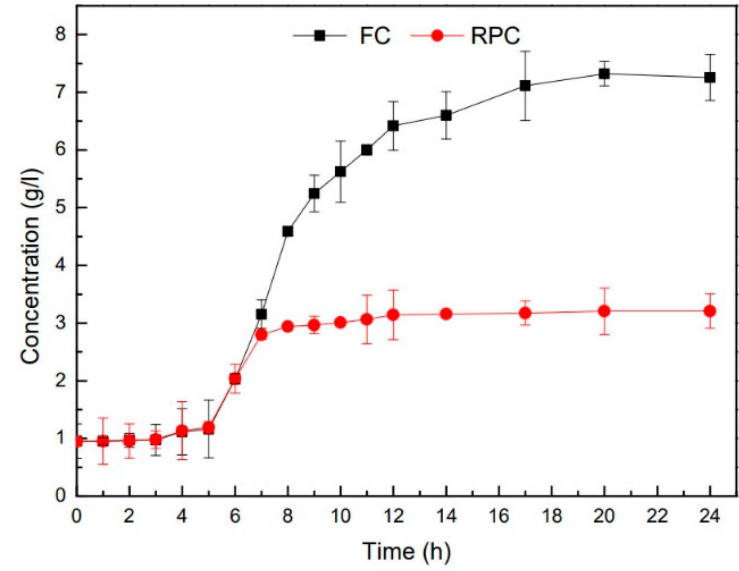

(b)

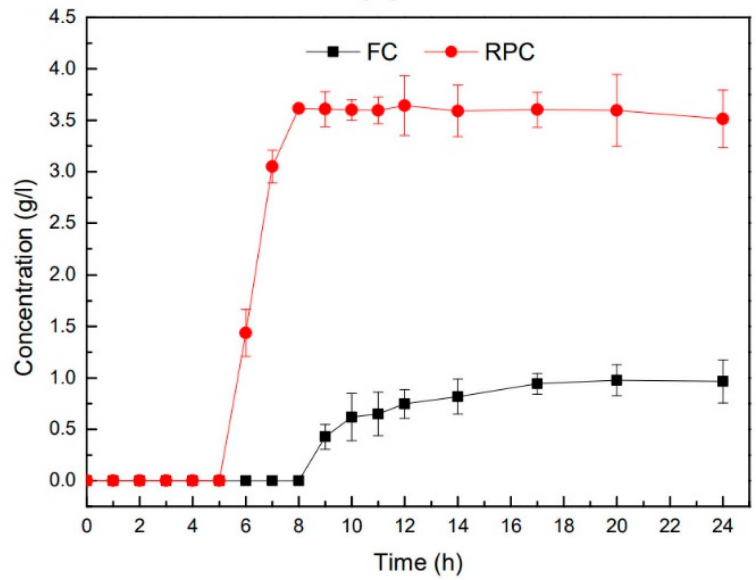

(d)

Figure 2. Metabolic production alterations of the strain E. faecalis LD33 cultured under FC and RPC. (a) Glucose, (b) lactate, (c) acetate, and (d) acetoin plus diacetyl, which all indicate the change of their concentration during the growth of $24 \mathrm{~h}$. RPC and FC mean E. faecalis LD33 cultured under respiration-permissive and fermentation conditions, respectively.

In contrast to supernatant glucose under FC, it was consumed less and more slowly until the 17th $\mathrm{h}$. However, glucose was mainly utilized to produce lactic acid during the fermentation metabolism, and the final $\mathrm{pH}$ dropped to 4.6. In contrast, glucose was mainly utilized in the respiratory metabolism to produce acetic acid, and the final $\mathrm{pH}$ increased significantly to 5.8 (Figures 1 and $2 \mathrm{a}, \mathrm{b}$ ).

Figure $2 \mathrm{~b}$ showed that at $6 \mathrm{~h}$, the lactic acid content of the supernatant under both culture conditions increased sharply. Two hours later, the lactic acid content of the supernatant under RPC reached the top, and the level remained unchanged for the rest of the whole period tested. In comparison, the lactic acid content of the supernatant under FC continued to accumulate as time passed. The trends of lactic acid production were the main factor affecting $\mathrm{pH}$ value, which caused it to continue to decline under FC and stop to decline until $8 \mathrm{~h}$ under RPC. In Figure 2c, higher acetate levels in RPC culture showed the most significant difference after $6 \mathrm{~h}$ of the growth, almost more than twice of that in FC culture; however, due to low acetic acid production, it contributed less to $\mathrm{pH}$ change compared to lactic acid.

Acetoin accumulates early during growth under RPC, and the amounts were clearly more than that in the other culture; the most incredible increment in acetoin occurred after $6 \mathrm{~h}$ of growth under RPC compared to that occurred after $8 \mathrm{~h}$ of growth under FC. These results can be seen in Figure 2d. Our results were in agreement with other previously 
reported in the literature. For example, Kaneko et al. [41] had reported that Lactococcus lactis subsp. lactis 3022 generated more biomass and transformed nearly all of the individual glucose substrate to both acetoin and diacetyl after being grown aerobically with hemin together with $\mathrm{Cu}^{2+}$. Duwat et al. [9] and Pedersen et al. [14] also reported that when respiration was activated by heme addition, lactic acid production was seen to diminish with an increase in the final $\mathrm{pH}$. In addition, the yields of neutral metabolic byproducts of acetoin and diacetyl were massively increased. Interestingly, the production of all the indicated composites might work as a metabolic safety valve to redirect pyruvate [18]. Pyruvate conversion to acetoin accounted for around $20 \%$ of each glucose carbon exercised during respiration [14].

\subsection{Antibacterial Effect of E. faecalis LD33 on the Pathogen during the Growth Modes}

In this study, the supernatants were obtained after being cultured under either FC or RPC for $24 \mathrm{~h}$ each. AWDA was used to test whether the strain could produce bacteriocins against both Gram-positive and Gram-negative bacteria. The results were shown in Table 1. The inhibition effect of E. faecalis LD33 grown under RPC on L. monocytogenes and S. aureus was significantly higher than those grown under FC $(p<0.05)$. The comparison of the inhibition effect on Salm. Typhimurium and Sh. Sonnei between both FC and RPC culture showed no significant difference $(p>0.05)$. The CFS of the strain under both culture conditions could not inhibit the growth of E. coli.

Table 1. Antibacterial activity of the strain E. faecalis LD33 on the selected pathogenic bacteria.

\begin{tabular}{cccccc}
\hline & \multicolumn{5}{c}{ Diameter of the Inhibition Zone (mm) } \\
\cline { 2 - 6 } & L. monocytogenes & S. aureus & E. coli & Salm. Typhimurium $^{\text {Sh. Sonnei }}$ \\
\hline LD33 R & $18.26 \pm 0.47^{\mathrm{d}}$ & $16.58 \pm 0.53^{\mathrm{c}}$ & - & $14.21 \pm 0.27^{\mathrm{ab}}$ & $17.81 \pm 0.49^{\mathrm{d}}$ \\
LD33 F & $14.55 \pm 0.25^{\mathrm{ab}}$ & $15.53 \pm 0.32^{\mathrm{b}}$ & - & $15.01 \pm 0.63^{\mathrm{b}}$ & $18.57 \pm 0.66^{\mathrm{d}}$ \\
\hline
\end{tabular}

All data were expressed as mean values \pm SD (n $>3) ; “ "$ "(negative) means no zone was observed; The diameter $(\mathrm{mm})$ of the inhibition zone contains the outside diameter of the Oxford cup $(8 \mathrm{~mm})$; Values followed by different letters are significantly different $(p<0.05)$; LD33R and LD33F mean E. faecalis LD33 cultured under respirationpermissive and fermentation conditions, respectively.

The results suggested that inhibition effects of E. faecalis LD33 cultured under different conditions were different. The inhibition effect of the CFS (organic acid eliminated) on the indicator bacteria was somehow caused by the production of bacteriocin by the strain during the metabolic progress [32,42]. When the CFSs of the cultures were treated with protease $\mathrm{K}$, pepsin and trypsin, the antibacterial activity for each was either decreased or abolished. Thus, we projected that the bacteriocin produced by E. faecalis LD33 might belong to Class lia bacteriocins, which virtually partly did the antagonistic activity against the selected food pathogens, as their actions were not upset by low or neutral pH values. The literature revealed that Class Iia bacteriocins have strong antibacterial activities against L. monocytogenes (for example) and contain a conserved YGNGVXCXXXXCXV sequence motif at their N-terminus [43]. The typical bacteriocins of LAB initially possess a confined antibacterial range and inactivate nearly associated bacteria exclusively [44,45]; however, E. faecalis LD33 produces bacteriocin with a broader inhibitory spectrum and a more potent antimicrobial activity, which inhibited the growth of Gram-positive pathogenic and spoilage bacteria (such as $S$. aureus and L. monocytogenes) as well as some Gram-negative species (Sh. Sonnei and Salm. Typhimurium) under respiration mode especially. That can be because $E$. faecalis LD33 could produce more acetic acid, acetoin, and diacetyl. In addition, such changes in metabolic pathways brought in more energy to produce much more secondary metabolite (including bacteriocin) during aerobic respiratory metabolism than fermentation. Besides bacteriocins, acetic acid, acetoin and diacetyl have been part and parcel of antimicrobial compounds [46,47]. 


\subsection{Tolerance of Acid and bile Salt and the Adherence Capability}

Acid and bile tolerances are considered as essential characteristics of LAB, enabling them to survive, grow and exert their probiotic functions in gastrointestinal transit [48-50]. The tolerance test results to acid and bile salt were shown in Figure 3a,b. The tolerance to low $\mathrm{pH}$ stress of E. faecalis LD33 was accounted for by the survival of cells of the strain treated $30 \mathrm{~min}$ in the GM17 broth of low pH $(2.9,2.6,2.3$ and 2.0) under FC and RPC. For both growth modes, the mortality of the strain increased as the $\mathrm{pH}$ decreased, though the cells that underwent fermentative mode were able to tolerant more acid stress. When the $\mathrm{pH}$ of the broth was 2.9, there was no significant difference between the acid resistance of the strain for both growth modes ( $p>0.05)$. At $\mathrm{pH} 2.0,2.3$ and 2.6, the survival cells of the strain for fermentation growth were significantly higher than that of respiring growth $(p<0.05)$. When $\mathrm{pH}$ reduced to 2.0 , a decrease of only $0.3 \mathrm{pH}$ unit from $\mathrm{pH} 2.3$ resulted in a drastic reduction in acid survival, translating to 5.2 and 6.0 in magnitude for FC and $\mathrm{RPC}$, respectively. Interestingly, a drop of just $0.15 \mathrm{pH}$ unit in both growth modes severely decreased acidic endurance.

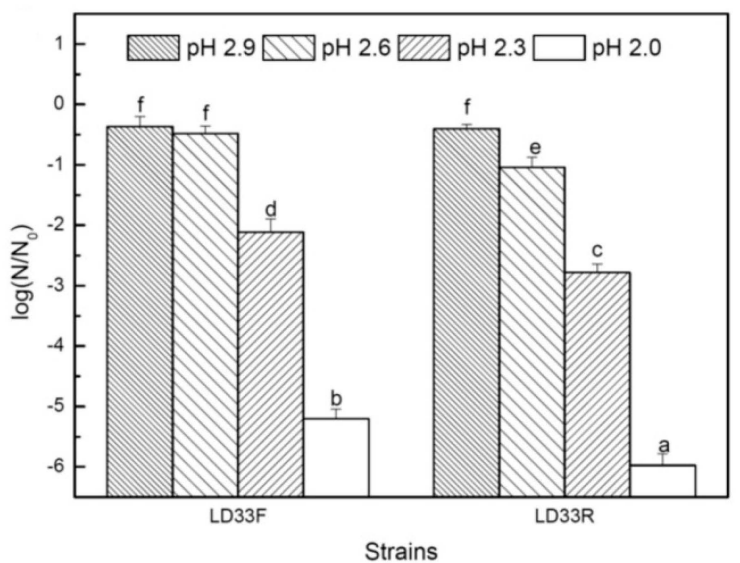

(a)

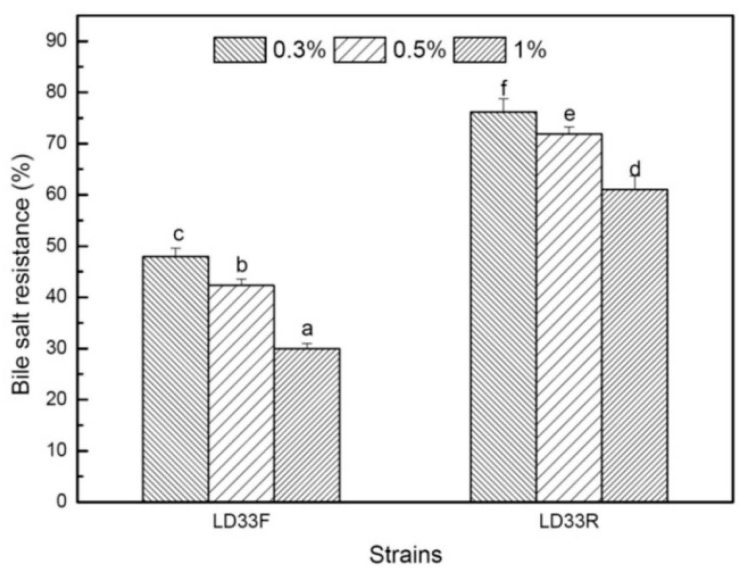

(b)

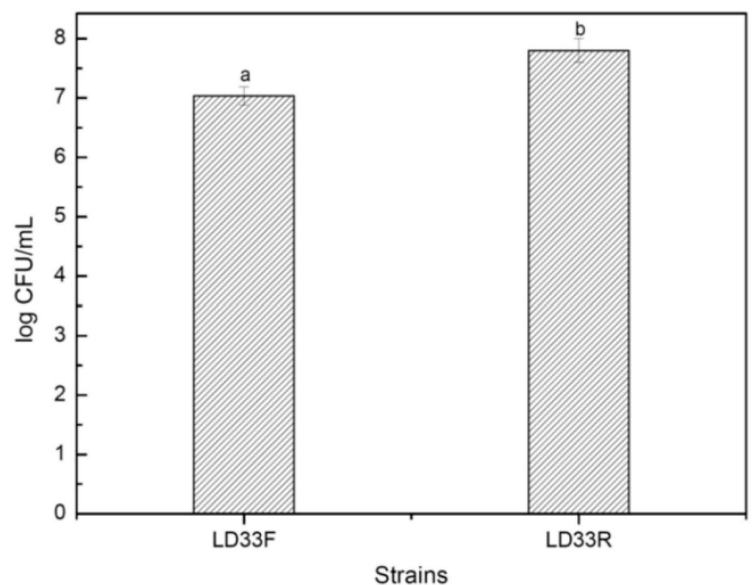

(c)

Figure 3. The probiotic effects of the strain E. faecalis LD33, including survival of E. faecalis LD33 (a) in an acid condition, (b) in bile salt condition, and (c) adhesion ability to colonic epithelium cells (HT-29 cells). LD33F and LD33R mean E. faecalis LD33 cultured under respiration-permissive and fermentation conditions, respectively. Different letters indicate significant differences $(p<0.05)$.

The variations in acid endurance of the various growth modes at decreasing $\mathrm{pH}$ roughly corresponded with the level of radical synthesis and membrane integrity. The same findings as Watanabe et al. [35] were reported, respiring cells were more sensitive to acid exposure while fermentative cells were more acid-resistant. They performed flow 
cytometry experiments at decreasing $\mathrm{pH}$ to assess the radical formation and cell membrane integrity. Finally, they suggest that sudden death because of critical low $\mathrm{pH}$ is associated with the formation of radicals and loss of membrane integrity; however, hemin could activate the intracellular catalase activity of the strains undergoing respiration, which could reduce the damage of such oxidants to cells; likewise, to some extent, the respiratory condition is most prone to radical formation.

The results of bile salt tolerance are shown in Figure $3 \mathrm{~b}$. The growth of E. faecalis LD33 was inhibited by all three concentrations of bile salts, and at the same concentration E. faecalis LD33 of respiring growth appeared better tolerant to bile salts as compared to that of fermentative growth $(p<0.05)$. When the salt concentration was increased, the survival rate of the strain in both growth modes declined. The adhesion ability to colonic epithelium cells was also a selection criterion for probiotic strains [51]. The difference in the adhesion ability of E. faecalis LD33 for both growth modes was shown in Figure 3c. After $3 \mathrm{~h}$ incubation with HT-29, the adhesion ability of the strain for respiring growth was more than that for fermentative growth. The differences in bile salt tolerance and adhesion ability between any strain undergoing respiring and fermentative growth have not been reported before. Our results suggested many differences in the acid and bile salt tolerance and the adherence ability of E. faecalis LD33 for the two growth modes. The differences may be caused by the different metabolites of these two respective metabolism modes.

\subsection{Growth Inhibition of HT-29 Human Colon Cancer Cells}

The anti-cancer effects on the HT-29 cells of the live bacteria and the supernatant of E. faecalis LD33 in both growth modes via the MTT test revealed considerable variation. The anti-proliferative activity is shown in Figure 4. After E. faecalis LD33 in both growth modes was cultured for $24 \mathrm{~h}$, the strains were co-cultured with the HT-29 colon cancer cells for $4 \mathrm{~h}$. The results indicated that regardless of the live respiring cells and the live fermentative cells, or supernatant of the culture of both modes played an inhibition effect on the proliferation of HT-29. With the bacterial cells count increasing, its inhibition effect on HT-29 cells has also been enhanced. However, compared with the live bacterial cells, the supernatant's inhibition effect was more significant $(p<0.05)$.

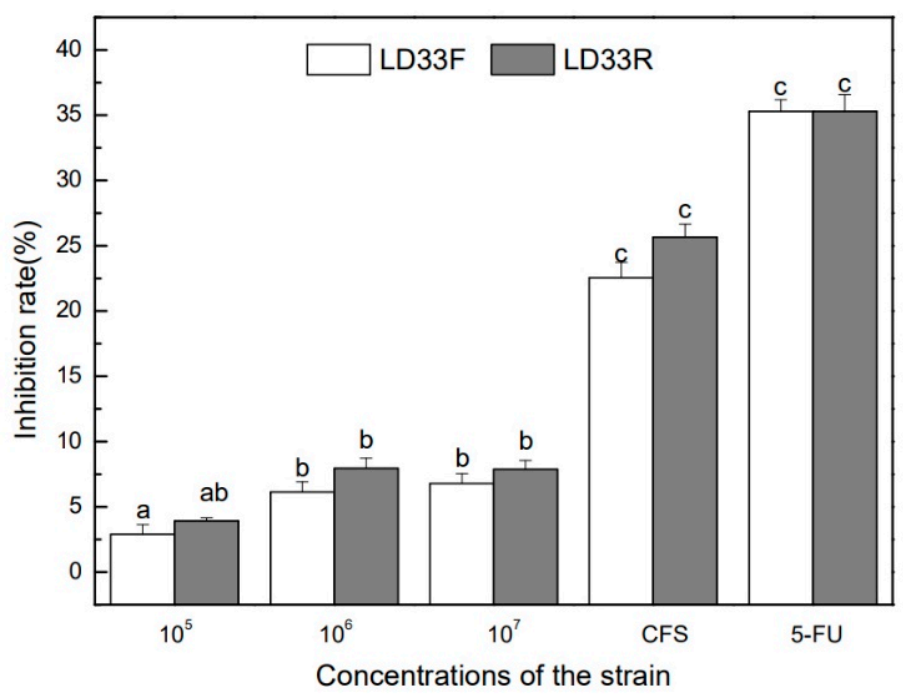

Figure 4. Inhibitory rates to HT-29 cells of E. faecalis LD33 cultured under FC and RPC. The four sample groups were different concentrations $\left(1 \times 10^{5}, 1 \times 10^{6}\right.$ and $\left.1 \times 10^{7} \mathrm{CFU} / \mathrm{mL}\right)$ of E. faecalis LD33 in HT-29 cells ( $10^{5}$ cells $\left./ \mathrm{mL}\right)$ suspension and the cell-free supernatant (CFS) of the strain. 5-FU $(7 \mu \mathrm{g} / \mathrm{mL})$ was used as a positive control. LD33F and LD33R mean E. faecalis LD33 cultured under respiration-permissive and fermentation conditions, respectively. Different letters indicate significant differences $(p<0.05)$. 
Moreover, there was no significant difference $(p>0.05)$ in inhibition effect between supernatant and the positive control 5-Fluorouracil (5-FU, $7 \mu \mathrm{g} / \mathrm{mL}$ ). The inhibition roles of all viable bacteria cells of E. faecalis LD33 $\left(1 \times 10^{5}, 1 \times 10^{6}\right.$, and $\left.1 \times 10^{7} \mathrm{CFU} / \mathrm{mL}\right)$ under both growth modes on HT-29 cells were significantly fragilethan that of 5-FU $(p<0.05)$. Previous reports claimed that whole bacterial cells of lactobacilli had anti-proliferative activities against colon cancer cell lines HT-29, HCT-116 and SNU-C4 [51-54]. This result suggested that the supernatant showed a superior anti-cancer effect than different concentration live cells; however, there was no clear distinction between the two growth modes tested. It is feasible that the growth inhibition came from the more comprehensive inhibitory spectrum and strong antimicrobial activity of bacteriocin produced by E. faecalis LD33. Other researchers have also encountered that some bacteriocins (such as nisin, pediocin PA-1, microcin E492, enterocin heterodimer and divercin V41) had a selective cytotoxic effect against cancer cells $[55,56]$; however, that still needs further exploration for potential cytotoxicity mechanisms towards HT-29 cells exhibited by the bacteriocin produced by E. faecalis LD33.

\section{Conclusions}

The growth of E. faecalis LD33 undergoing respiration could bring unprecedented transformations of higher biomass and more flavor metabolites such as acetoin and diacetyl. The presumed bacteriocins and bacteriocin-like substances produced by E. faecalis LD33 had a broader inhibitory spectrum. Moreover, E. faecalis LD33 led a vigorous antimicrobial activity to L. monocytogenes and S. aureus and displayed a better performance to bile salt and adherence capability when underwent respiring growth. E. faecalis LD33 also had anti-proliferative activities against colon cancer cell lines HT-29. Its supernatant showed a superior anti-cancer effect than different concentrations of live cells, even if there was no significant difference between supernatant and the $7 \mu \mathrm{g} / \mathrm{mL}$ of 5-Fluorouracil. On the anti-cancer effect of E. faecalis LD33, there was no significant difference between the two growth modes. As a result, E. faecalis LD33 with respiration capacity can be a good strain for further research and applications in food, agriculture and pharmaceuticals.

Author Contributions: Conceptualization, Y.J., F.L. and L.Z.; methodology, Y.J., S.Z. and F.L.; software, Y.J. and S.Z.; validation, F.L. and H.Y.; resources, F.L. and L.Z.; writing一original draft preparation, Y.J.; writing-review and editing, F.L., N.S. and H.Y.; visualization, Y.J. and F.L.; supervision, F.L. and L.Z.; project administration, Y.J. and F.L.; funding acquisition, F.L. and Y.J. All authors have read and agreed to the published version of the manuscript.

Funding: This work was co-financed by the National Natural Science Foundation of China (No. 32072190 and 32101929), and Academic Backbone Plan of Northeast Agricultural University (No. 20XG12).

Institutional Review Board Statement: Not applicable.

Informed Consent Statement: Not applicable.

Data Availability Statement: The data presented in this study are available on request from the corresponding author.

Conflicts of Interest: The authors declare no conflict of interest.

\section{References}

1. Lechardeur, D.; Cesselin, B.; Fernandez, A.; Lamberet, G.; Garrigues, C.; Pedersen, M.; Gaudu, P.; Gruss, A. Using heme as an energy boost for lactic acid bacteria. Curr. Opin. Biotechnol. 2011, 22, 143-149. [CrossRef] [PubMed]

2. Andersen, H.W.; Pedersen, M.B.; Hammer, K.; Jensen, P.R. Lactate dehydrogenase has no control on lactate production but has a strong negative control on formate production in Lactococcuslactis. JBIC J. Biol. Inorg. Chem. 2001, 268, 6379-6389. [CrossRef]

3. Kawai, M.; Harada, R.; Yoda, N.; Yamasaki-Yashiki, S.; Fukusaki, E.; Katakura, Y. Suppression of lactate production by using sucrose as a carbon source in lactic acid bacteria. J. Biosci. Bioeng. 2020, 129, 47-51. [CrossRef] [PubMed]

4. Leroy, F.; De Vuyst, L. Lactic acid bacteria as functional starter cultures for the food fermentation industry. Trends Food Sci. Technol. 2004, 15, 67-78. [CrossRef] 
5. Caplice, E. Food fermentations: Role of microorganisms in food production and preservation. Int. J. Food Microbiol. 1999, 50, 131-149. [CrossRef]

6. Mun, S.; Seo, Y.; Chan, G.H.C. Characterization of the psychrotrophic lactic acid bacterium, Leuconostocgelidum subsp. aenigmaticum LS4 isolated from kimchi based on comparative analyses of its genomic and phenotypic properties. aenigmaticum LS4 Isolated from Kimchi Based on Comparative Analyses of Its Genomic and Phenotypic Properties. Foods 2021, $10,1889$.

7. Zhang, H.; Xu, J.; Chen, Q.; Wang, H.; Kong, B. Physiological, Morphological and Antioxidant Responses of Pediococcuspentosaceus R1 and Lactobacillusfermentum R6 Isolated from Harbin Dry Sausages to Oxidative Stress. Foods 2021, 10, 1203. [CrossRef] [PubMed]

8. Konings, W.N. The cell membrane and the struggle for life of lactic acid bacteria. AntonieVan Leeuwenhoek 2002, 82, 3-27. [CrossRef]

9. Duwat, P.; Sourice, S.; Cesselin, B.; Lamberet, G.; Vido, K.; Gaudu, P.; Le Loir, Y.; Violet, F.; Loubière, P.; Gruss, A. Respiration Capacity of the Fermenting Bacterium Lactococcuslactis and Its Positive Effects on Growth and Survival. J. Bacteriol. 2001, 183, 4509-4516. [CrossRef]

10. Gaudu, P.; Vido, K.; Cesselin, B.; Kulakauskas, S.; Tremblay, J.; Rezaïki, L.; Lamberet, G.; Sourice, S.; Duwat, P.; Gruss, A. Respiration capacity and consequences in Lactococcuslactis. AntonieVan Leeuwenhoek 2002, 82, 263-269. [CrossRef]

11. Winstedt, L.; Frankenberg, L.; Hederstedt, L.; von Wachenfeldt, C. Enterococcus faecalis V583 Contains a Cytochrome bd-Type Respiratory Oxidase. J. Bacteriol. 2000, 182, 3863-3866. [CrossRef] [PubMed]

12. Sijpesteijn, A.K. Induction of cytochrome formation and stimulation of oxidative dissimilation by hemin in Streptococcus lactis and Leuconostocmesenteroides. AntonieVan Leeuwenhoek 1970, 36, 335-348. [CrossRef] [PubMed]

13. Watanabe, M.; van der Veen, S.; Nakajima, H.; Abee, T. Effect of respiration and manganese on oxidative stress resistance of Lactobacillus plantarum WCFS1. Microbiology 2012, 158, 293-300. [CrossRef]

14. Pedersen, M.B.; Gaudu, P.; Lechardeur, D.; Petit, M.-A.; Gruss, A. Aerobic Respiration Metabolism in Lactic Acid Bacteria and Uses in Biotechnology. Annu. Rev. Food Sci. Technol. 2012, 3, 37-58. [CrossRef] [PubMed]

15. Watthanasakphuban, N.; Virginia, L.; Haltrich, D.; Peterbauer, C. Analysis and Reconstitution of the Menaquinone Biosynthesis Pathway in Lactiplantibacillusplantarum and Lentilactibacillusbuchneri. Microorganisms 2021, 9, 1476. [CrossRef] [PubMed]

16. Zotta, T.; Parente, E.; Ricciardi, A. Aerobic metabolism in the genus Lactobacillus: Impact on stress response and potential applications in the food industry. J. Appl. Microbiol. 2017, 122, 857-869. [CrossRef]

17. Razvi, A.; Zhang, Z.; Lan, C.Q. Effects of glucose and nitrogen source concentration on batch fermentation kinetics of Lactococcuslactis under hemin-stimulated respirative condition. Biotechnol. Prog. 2008, 24, 852-858. [CrossRef]

18. Cesselin, B.; Garrigues, C.; Pedersen, M.B.; Roussel, C.; Gruss, A.; Gaudu, P. Task Distribution between Acetate and Acetoin Pathways to Prolong Growth in Lactococcuslactis under Respiration Conditions. Appl. Environ. Microbiol. 2018, 84, e01005-18. [CrossRef]

19. Ricciardi, A.; Zotta, T.; Ianniello, R.G.; Boscaino, F.; Matera, A.; Parente, E. Effect of Respiratory Growth on the Metabolite Production and Stress Robustness of Lactobacillus casei N87 Cultivated in Cheese Whey Permeate Medium. Front. Microbiol. 2019, 10, 851. [CrossRef]

20. Zotta, T.; Ricciardi, A.; Ianniello, R.G.; Storti, L.V.; Glibota, N.A.; Parente, E. Aerobic and respirative growth of heterofermentative lactic acid bacteria: A screening study. Food Microbiol. 2018, 76, 117-127. [CrossRef]

21. Tachon, S.; Brandsma, J.B.; Yvon, M. NoxE NADH Oxidase and the Electron Transport Chain Are Responsible for the Ability of Lactococcuslactis to Decrease the Redox Potential of Milk. Appl. Environ. Microbiol. 2010, 76, 1311-1319. [CrossRef] [PubMed]

22. Johanson, A.; Goel, A.; Olsson, L.; Franzén, C.J. Respiratory Physiology of Lactococcuslactis in Chemostat Cultures and Its Effect on Cellular Robustness in Frozen and Freeze-Dried Starter Cultures. Appl. Environ. Microbiol. 2020, 86, e02785-19. [CrossRef] [PubMed]

23. Siciliano, R.A.; Pannella, G.; Lippolis, R.; Ricciardi, A.; Mazzeo, M.F.; Zotta, T. Impact of aerobic and respirative life-style on Lactobacillus casei N87 proteome. Int. J. Food Microbiol. 2019, 298, 51-62. [CrossRef]

24. Wunderlich, P.; Braun, L.; Fumagalli, I.; D’Apuzzo, V.; Heim, F.; Karly, M.; Lodi, R.; Politta, G.; Vonbank, F.; Zeltner, L. DoubleBlind Report on the Efficacy of Lactic Acid-Producing Enterococcus SF68 in the Prevention of Antibiotic-Associated Diarrhoea and in the Treatment of Acute Diarrhoea. J. Int. Med Res. 1989, 17, 333-338. [CrossRef]

25. Chang, C.-I.; Liu, W.-Y. An evaluation of two probiotic bacterial strains, Enterococcus faecium SF68 and Bacillus toyoi, for reducing edwardsiellosis in cultured European eel, Anguilla anguilla L. J. Fish Dis. 2002, 25, 311-315. [CrossRef]

26. Veir, J.K.; Knorr, R.; Cavadini, C.; Sherrill, S.J.; Benyacoub, J.; Satyaraj, E.; Lappin, M.R. Effect of supplementation with Enterococcus faecium (SF68) on immune functions in cats. Veter-Ther. Res. Appl. Veter-Med. 2007, 8, 229-238.

27. Buydens, P.; Debeuckelaere, S. Efficacy of SF 68 in the Treatment of Acute Diarrhea a Placebo-Controlled Trial. Scand. J. Gastroenterol. 1996, 31, 887-891. [CrossRef]

28. Benyacoub, J.; Pérez, P.F.; Rochat, F.; Saudan, K.Y.; Reuteler, G.; Antille, N.; Humen, M.; De Antoni, G.L.; Cavadini, C.; Blum, S.; et al. Enterococcus faecium SF68 Enhances the Immune Response to Giardia intestinalis in Mice. J. Nutr. 2005, 135, 1171-1176. [CrossRef]

29. Franz, C.M.; Huch, M.; Abriouel, H.; Holzapfel, W.; Galvez, A. Enterococci as probiotics and their implications in food safety. Int J. Food Microbiol. 2011, 151, 125-140. [CrossRef]

30. Andersen, H.W.; Solem, C.; Hammer, K.; Jensen, P.R. Twofold Reduction of Phosphofructokinase Activity in Lactococcuslactis Results in Strong Decreases in Growth Rate and in Glycolytic Flux. J. Bacteriol. 2001, 183, 3458-3467. [CrossRef] 
31. Starrenburg, M.J.C.; Hugenholtz, J. Citrate Fermentation by Lactococcus and Leuconostoc spp. Appl. Environ. Microbiol. 1991, 57, 3535-3540. [CrossRef] [PubMed]

32. Ammor, S.; Tauveron, G.; Dufour, E.; Chevallier, I. Antibacterial activity of lactic acid bacteria against spoilage and pathogenic bacteria isolated from the same meat small-scale facility: 1-Screening and characterization of the antibacterial compounds. Food Control 2006, 17, 454-461. [CrossRef]

33. Thirabunyanon, M.; Boonprasom, P.; Niamsup, P. Probiotic potential of lactic acid bacteria isolated from fermented dairy milks on antiproliferation of colon cancer cells. Biotechnol. Lett. 2008, 31, 571-576. [CrossRef] [PubMed]

34. Moraes, P.; Perin, L.; Todorov, S.; Silva, A.; Franco, B.; Nero, L. Bacteriocinogenic and virulence potential of Enterococcus isolates obtained from raw milk and cheese. J. Appl. Microbiol. 2012, 113, 318-328. [CrossRef]

35. Watanabe, M.; van der Veen, S.; Abee, T. Impact of Respiration on Resistance of Lactobacillus plantarum WCFS1 to Acid Stress. Appl. Environ. Microbiol. 2012, 78, 4062-4064. [CrossRef] [PubMed]

36. Succi, M.; Tremonte, P.; Reale, A.; Sorrentino, E.; Grazia, L.; Pacifico, S.; Coppola, R. Bile salt and acid tolerance of Lactobacillusrhamnosus strains isolated from Parmigiano Reggiano cheese. FEMS Microbiol. Lett. 2005, 244, 129-137. [CrossRef] [PubMed]

37. Chauviere, G.; Coconnier, M.-H.; Kerneis, S.; Fourniat, J.; Servin, A.L. Adhesion of human Lactobacillus acidophilus strain LB to human enterocyte-like Caco-2 cells. J. Gen. Microbiol. 1992, 138, 1689-1696. [CrossRef]

38. Zhang, Y.; Zhang, L.W.; Du, M.; Yi, H.; Guo, C.; Tuo, Y.; Han, X.; Li, J.; Zhang, L.; Yang, L. Antimicrobial activity against Shigellasonnei and probiotic properties of wild lactobacilli from fermented food. Microbiol. Res. 2011, 167, 27-31. [CrossRef]

39. Haza, A.I.; Zabala, A.; Morales, P. Protective effect and cytokine production of a Lactobacillus plantarum strain isolated from ewes milk cheese. Int. Dairy J. 2004, 14, 29-38. [CrossRef]

40. Pedersen, M.B.; Garrigues, C.; Tuphile, K.; Brun, C.; Vido, K.; Bennedsen, M.; Møllgaard, H.; Gaudu, P.; Gruss, A. Impact of Aeration and Heme-Activated Respiration on Lactococcuslactis Gene Expression: Identification of a Heme-Responsive Operon. J. Bacteriol. 2008, 190, 4903-4911. [CrossRef]

41. Kaneko, T.; Takahashi, M.; Suzuki, H. Acetoin Fermentation by Citrate-Positive Lactococcuslactis subsp. lactis 3022 Grown Aerobically in the Presence of Hemin or $\mathrm{Cu}^{2+}$. Appl. Environ. Microbiol. 1990, 56, 2644-2649. [CrossRef] [PubMed]

42. Pangsomboon, K.; Kaewnopparat, S.; Pitakpornpreecha, T.; Srichana, T. Antibacterial activity of a bacteriocin from Lactobacillusparacasei HL32 against Porphyromonasgingivalis. Arch. Oral Biol. 2006, 51, 784-793. [CrossRef] [PubMed]

43. Liu, W.; Zhang, L.; Yi, H.; Shi, J.; Xue, C.; Li, H.; Jiao, Y.; Shigwedha, N.; Du, M.; Han, X. Qualitative detection of class IIabacteriocinogenic lactic acid bacteria from traditional Chinese fermented food using a YGNGV-motif-based assay. J. Microbiol. Methods 2014, 100, 121-127. [CrossRef]

44. Yi, H.; Zhang, L.; Han, X.; Du, M.; Zhang, Y.; Li, J.; Sun, K.; Hou, Y. Isolation and applied potential of lactic acid bacteria from Chinese traditional fermented food in specific ecological localities. Food Sci. Biotechnol. 2011, 20, 1685-1690. [CrossRef]

45. Valledor, S.J.D.; Dioso, C.M.; Bucheli, J.E.V.; Park, Y.J.; Suh, D.H.; Jung, E.S.; Kim, B.; Holzapfel, W.H.; Todorov, S.D. Characterization and safety evaluation of two beneficial, enterocin-producing Enterococcus faecium strains isolated from kimchi, a Korean fermented cabbage. Food Microbiol. 2022, 102, 103886. [CrossRef] [PubMed]

46. Alharbi, N.K.; Alsaloom, A.N. Characterization of Lactic Bacteria Isolated from Raw Milk and Their Antibacterial Activity against Bacteria as the Cause of Clinical Bovine Mastitis. J. Food Qual. 2021, 2021, 6466645. [CrossRef]

47. Terzić-Vidojević, A.; Veljović, K.; Tolinački, M.; Živković, M.; Lukić, J.; Lozo, J.; Fira, D.; Jovčić, B.; Strahinić, I.; Begović, J.; et al. Diversity of non-starter lactic acid bacteria in autochthonous dairy products from Western Balkan Countries-Technological and probiotic properties. Food Res. Int. 2020, 136, 109494. [CrossRef]

48. Ma, J.; Xu, C.; Yu, H.; Feng, Z.; Yu, W.; Gu, L.; Liu, Z.; Chen, L.; Jiang, Z.; Hou, J. Electro-encapsulation of probiotics in gum Arabic-pullulan blend nanofibres using electrospinning technology. Food Hydrocoll. 2021, 111, 106381. [CrossRef]

49. De Matos, F.E., Jr.; da Silva, M.P.; Kasemodel, M.G.C.; Santos, T.T.; Burns, P.; Reinheimer, J.; Vinderola, G.; Favaro-Trindade, C.S. Evaluation of the viability and the preservation of the functionality of microencapsulated Lactobacillusparacasei BGP1 and Lactobacillusrhamnosus 64 in lipid particles coated by polymer electrostatic interaction. J. Funct. Foods 2019, 54, 98-108. [CrossRef]

50. Ester, B.; Noelia, B.; Laura, C.-J.; Francesca, P.; Cristina, B.; Rosalba, L.; Marco, D.R. Probiotic survival and in vitro digestion of L. salivarius spp. salivarius encapsulated by high homogenization pressures and incorporated into a fruit matrix. LWT 2019, 111, 883-888. [CrossRef]

51. Tuo, Y.; Zhang, L.; Yi, H.; Zhang, Y.; Zhang, W.; Han, X.; Du, M.; Jiao, Y.; Wang, S. Short communication: Antiproliferative effect of wild Lactobacillus strains isolated from fermented foods on HT-29 cells. J. Dairy Sci. 2010, 93, 2362-2366. [CrossRef] [PubMed]

52. Wang, S.-M.; Zhang, L.-W.; Fan, R.-B.; Han, X.; Yi, H.-X.; Zhang, L.-L.; Xue, C.-H.; Li, H.-B.; Zhang, Y.-H.; Shigwedha, N. Induction of HT-29 cells apoptosis by lactobacilli isolated from fermented products. Res. Microbiol. 2014, 165, 202-214. [CrossRef] [PubMed]

53. Park, K.; Bong, Y.; Kim, H. Fermentation characteristic and increased health functionality of kimchi by kimchi lactic acid bacteria starters (644.14). FASEB J. 2014, 28, 644.14. [CrossRef]

54. Chang, J.; Shim, Y.; Cha, S.; Chee, K. Probiotic characteristics of lactic acid bacteria isolated from kimchi. J. Appl. Microbiol. 2010, 109, 220-230. [CrossRef] 
55. Özel, B.; Şimşek, Ö.; Akçelik, M.; Saris, P.E.J. Innovative approaches to nisin production. Appl. Microbiol. Biotechnol. 2018, 102, 6299-6307. [CrossRef]

56. Buss, G.P.; Wilson, C.M. Exploring the cytotoxic mechanisms of Pediocin PA-1 towards HeLa and HT29 cells by comparison to known bacteriocins: Microcin E492, enterocin heterodimer and Divercin V41. PLoS ONE 2021, 16, e0251951. [CrossRef] 